\title{
Why Public Administration?
}

\author{
by Stephen Joel Trachtenberg \\ President Emeritus and University Professor of Public Service \\ The George Washington University
}

When I was a senior at Columbia in 1959, the dean, John Gorham Palfrey, asked me what I was planning to do after I got my BA. I told him I was debating between pursuing a law degree and a master's degree in public administration (MPA). He encouraged me to go to law school. He said the MPA was too new and that even if I intended to make my career in government service, I would be better off with an LLB (now a JD) because nobody was quite sure what the MPA stood for whereas most people understood what the law degree represented. I took his advice and went to law school. And, after graduating from Yale, I spent two years with the US Atomic Energy Commission and then worked as an aide to the US congressman from South Bend, Indiana.

But ultimately I could not resist going to Harvard for my MPA, and I'm glad I did. It helped me to focus and integrate what I had learned as an undergraduate and at professional school and on the job in a way that has been of catalytic importance throughout my career. Being a lawyer has been remarkably helpful but the master's degree in public administration gave me special insights and competencies.

Almost half a century after my conversation with Dean Palfrey, someone else asked me a similar seminal question. No one has ever accused me of being a retiring man. So in 2007, when the chairman of the board of trustees took me out to lunch as I was retiring after 19 years from the presidency of The George Washington University and proposed that a school at GW be designated in my honor, I had an uncharacteristic reaction: the idea made me feel humble. I responded with gratitude.

When the chairman gave me a choice of schools and/or programs to be named, he seemed surprised when I chose public policy and public administration. He wondered why I hadn't asked for one of the larger, more developed schools or one with a building completely of its own. I explained that my entire career had been either in public service (first in the Kennedy administration, then in the Johnson administration following some time on the Hill) or in academic work (as a professor, dean, vice-president, and a president at three universities). Also, I am inclined philosophically to buy low and sell high, following advice my father gave me about investing.

The initiative to begin a master's of public administration degree at GW in 1963 came from President John F. Kennedy's inspiration and therefore the university accurately claims 50 years of professional education for those committed to government service. Twenty-five years after its founding as a department, I recall the academic and political struggle to create a distinct school of public policy and public administration within the college of arts and sciences; it has only been since 2003 that a distinctive 
School of Public Policy and Public Administration has been part of the university family. And 2013 marks a milestone as the $20^{\text {th }}$ year in which Policy Perspectives has been published. We are indeed celebrating many historic beginnings.

In many ways, I believe the full-glory of the School of Public Policy and Public Administration lies ahead, its half-century of contributions not withstanding. It is, as we all know, one of the best of its kind in the country. Since coming to GW as president in 1988 and asking for an academic appointment to public administration, I have believed it to have almost limitless potential to become the preeminent school of its kind in the nation. We have a resource that few can match, a location that defines our mission of service: an internationally-renowned school of public administration in the world's capital of policymakers.

On a personal level, it still seems to be just a little bit odd to step off the elevator each morning on my way to work and read "The Trachtenberg School of Public Policy and Public Administration" in bold letters on the wall. I confess that it moves me every time, in much the same way I am persistently touched when I see the Capitol as I drive along Pennsylvania Avenue. It is a source of great satisfaction for me to be associated with the faculty and the students of our school, and I remain delighted to introduce myself each year at the first faculty meeting of the fall semester when we greet returning and particularly new colleagues. I hope to remain among you contributing as best I can for many years to come. 